ネルギーの散逸過程である砕波が説明できたということ は，水面の運動量損失のプロセスを害現したということに なりますので，計算上も運動量損失が実現されていると考 えられます。しかし，散逸プロセスについては，自由表面
乱流モデル化していないこと，計算精度の低さから数值的 な散逸が大きいことの2つの理由により，現状では大変不 充分な結果しか得られないと考えられます。

\title{
5 渦格子法によるスーパーキャビテーティング・プロペラの設計
}

【討論】千葉規風君 (1) 本論文の SRIJ-IVハイブ リッド・プロペラは 25 年前, 翼先端部のエロージョン防止 对策の 1 つとして考えた特部第 670162 号と同じ構成で, そ れが，スーパーキャビテーティングプロペラとして有効で あることが本論文でも示されており，興味深く拝見しまし た。

（2）SRIJ-IVは，Fig.11の計算でも，Fig.13の実験で も，設計点 $J=1.1$ において翼根部前緑からキャビテーショ ンが発生して扔りますが，翼根部をサブキャビであるエ〉 ロフォイル翼型にしたこととの関係はどのように考えれば よいのでしょうか。

（3）空洞試験での流速，静压の計測位買*) はどのよう になって扔りましたでしうか。

・谷林，千堡「模型ア゚ロペラのキャビテーション水槽試験におけ

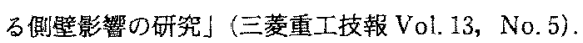

【回答】（1）本論文のSCP 設部において用いたハイフ リッドプロペラ,小展開面積比プロペラなどのアイデアは, 発想において一部暴なる点があるにしても，通常型プロペ ラにおいても古くからあるアイデアです。本研究において は，それらのアイデアをSCPの理論設計法の中で実現し， それらの有効性を明らかにすることができました。しかし， ご指摘の特許も，本論文の SRIJ-IVも使う翼断面は SC 翼 型かエアロフォイル翼型かという二元的な発想であり, 過 渡領域は流体力学的な襄付けの無い形状となっています。 将来的には SC 翼型もエアロフォイル翼型も統一的に考元 て，各半径位置において最も適した断面形状を連続的に設
計できる手法が期待されます。

（2）SC 翼型では翼後緑が厚く，SC 状態の時にはこの 後縁がキャビティの内部にあるために特に問題とはなりま せんが，非キャビテーション状態あるいは部分キャビテー ション状態の時には翼後縁の後ろに大きな例離域ができ， これが抵抗となります。ハイブリッド型ブロペラでは, 翼 根部の翼断面を後縁の薄いエアロフォイル翼型にし，この 抵抗が小さくなるようにしています。エアロフォイル翼型 にすることにより非キャビテーション状態となることを期 待しているものではなく，予測計算，実験結果ともに翼根 に関しては犋い通りのキャビテーション状態が得られてい ます。な挹，Fig. 11 で翼根部の後緑の後ろに小さなキャビ テーション領域があるのは短いベースベンティッドキャビ テーションです。さらに効率向上を目指すならば，部分キ ヤビテーションを伴うべースベンティドキャビテーション 状態て性能の良い翼型を開発することが考えられます。

（3）流速は，プロペラ計測位置前方の縮流部に $2.28 \mathrm{~m}$ 離して設けられた 2 断面において静圧を計測し，その差圧 よりベンチュリー方式により求めた流速に, Wood \& Har. risの方法による僋壁影響補正を行っています。計湘部の静 压は，プロペラ位置直下より上下流方向に各 $480 \mathrm{~mm}$ 離九 た2点の静圧を平均して求めています。プロペラ真横にピ ト一管を配置して流速, 静圧を設定したときと比べて, 訢 測結果にほとんど差のないことは，通常のプロベラ計測に ついて調べております。

\section{6 外洋ヨットの転覆現象に及ぼす船型等の影響について}

【討論】野本謙作 君 マストトップの浮体注既に双胴 ヨットではかなり広く採用されていますが，普通の単胴艇 での効果が定量的に示された意義は大きいと思います。常 時着けておくならば双胴艇で使われているような“空飛ぶ 円板型”が風圧等から考えてよいでしょう。それでも有効 な体積を常時著けるのは種々の問題があるかも知れませ 几。転覆時自動膨張させるのも一案, また比較的他との干 涉が少ないという点でスプレダに着けることも一案かと思
います。

ヨットの survival stability に復原力消失角が基本的に 重要であると言う知兒は今回の研究の大きな結論と思いま す。その数字として，個人的には $100^{\circ}$ は誤解を生ずるおて れを感じます。倒立静止すると急速な浸水が起こりこれが 倒立時安定に大きい影響をもちますが，この要素も考慮に 入れると最小 $120^{\circ}$ ，でき机ば $130^{\circ} \sim 140^{\circ}$ を目安にできるの ではないかと考えています。 